\title{
Self-, cross- and interspecific pollinations in Passiflora capsularis and P. rubra ${ }^{1}$
}

\author{
JULIANE DOS SANTOS AMORIM², MARGARETE MAGALHÃES SOUZA², \\ AMÉRICO JOSÉ CARVALHO VIANA² and JÔSIE CLOVIANE DE OLIVEIRA FREITAS²
}

(received: December 02, 2010; accepted: November 10, 2011)

\begin{abstract}
Self-, cross- and interspecific pollinations in Passiflora capsularis and P. rubra). This study aimed to characterize the reproductive system of Passiflora capsularis L. and P. rubra L. In vivo controlled pollinations, in vitro pollen germination and pollen-ovule (P:O) ratio evaluation were conducted. In self-pollination, intraspecific and interspecific pollination, $P$. capsularis showed means of $62.5,68.7$ and $48.4 \%$ of fertilized flowers, while in $P$. rubra, the averages were $67.2,62.5$ and $46.9 \%$, respectively. For in vitro germination, $52.2 \%$ of $P$. capsularis pollen grains germinated while in $P$. rubra, the percentage was 64.4. The P:O ratio was 22.4 for P. capsularis, and 27.4 for $P$. rubra, which included them in the category of obligatory autogamous. Passiflora capsularis and P. rubra can reproduce both by self-pollination and cross-pollination, and crossings between the two species succeeded though the success rate was lower than $50 \%$. The characteristics of the reproductive system of both species allow the use of greater range of options on breeding methods for production of ornamental Passiflora plants.
\end{abstract}

Key words - in vivo pollination, in vitro germination, passion flower, pollen-ovule ratio

RESUMO - (Autopolinização, polinização cruzada e polinização interespecífica em Passiflora capsularis e P. rubra). O presente trabalho objetivou caracterizar o sistema reprodutivo de Passiflora capsularis L. e P. rubra L. Foram realizadas polinizações controladas in vivo, germinação in vitro do pólen e razão pólen:óvulo (P:O). Nas autopolinizações, polinizações intra-específicas e interespecíficas, $P$. capsularis apresentou em média $62,5,68,7$ e 48,4\% de flores fertilizadas, enquanto em $P$. rubra a média foi de $67,2,62,5$ e 46,9\%, respectivamente. Na germinação in vitro, $52,2 \%$ dos grãos de pólen de $P$. capsularis germinaram, enquanto em $P$. rubra o percentual foi $64,4 \%$. A razão P:O foi 22,4 para $P$. capsularis e 27,4 para $P$. rubra, que as incluiu na categoria de autógamas obrigatórias. Passiflora capsularis e . rubra podem se reproduzir por autopolinização e polinização cruzada, e cruzamentos entre as duas espécies foram bem sucedidos mesmo com baixa taxa de sucesso (menos de 50\%). As características do sistema reprodutivo de ambas as espécies permitem a utilização de maiores opções de métodos de melhoramento para produção de plantas ornamentais de Passiflora.

Palavras-chave - germinação in vitro, maracujazeiros, polinização in vivo, razão pólen-óvulo

\section{Introduction}

The Passifloraceae is composed by 19 genera (Bernacci et al. 2003) and about 700 species (Feuillet 2004). The plants are herbaceous or woody, and extrafloral nectaries can be detected (Barroso et al. 1978). The most striking morphological characteristic of the family is the presence of corona filaments in the flowers, which supports the group monophyly (Judd et al. 1999). Passiflora is distributed mainly in tropical and subtropical regions, but they better develop in the climate of the Americas and Africa (Cronquist 1981, Judd et al. 1999). According to Cervi (2005), the genus comprises

\footnotetext{
1. Parte da dissertação de mestrado da primeira autora, Programa de Pós-Graduação em Genética e Biologia Molecular, Universidade Estadual de Santa Cruz, BA, Brazil.

2. Universidade Estadual de Santa Cruz, Departamento de Ciências Biológicas, Pavilhão Jorge Amado, Rodovia Ilhéus-Itabuna, km 16, 45662-900 Ilhéus, BA, Brazil.

3. Corresponding author: souzamagg@yahoo.com.br.
}

about 520 species, but new species have been discovered (Cervi 2006, Nunes \& Queiroz 2007, Viana 2009). Brazil has a privileged status on the genetic resources of Passiflora, which presents a wide genetic variability available for use in breeding programs (Meletti et al. 2000). Among the Brazilian states, Bahia stands out showing significant occurrence of Passiflora, where 45 species were reported by Nunes (2002).

There is a wide diversity of reproductive strategies in angiosperms present in different communities (Richards 1986). Intraspecific and interspecific crossings comprehend important tools in genetic breeding programs. They are fundamental for the development of new varieties, once hybridization increases heterosis by the occurrence of new combinations of genes encoding agronomically important traits (Borém 1999, Paterniani 2001). Self-pollination may lead to loss in genetic variability due to inbreeding depression, which is a phenomenon aggravated in rare species (Reis et al. 2005). 
Many Passiflora species are usually selfincompatible, requiring cross-pollination (Bruckner et al. 1995). Passiflora flowers attract a wide range of pollinators, but their pollination is mainly performed by insects, such as carpenters bees of the genus Xylocopa Latr., bees of the genus Ptiloglossa Smith, and wasps and moths (Koschnitzke \& Sazima 1997). A mechanism to increase genetic variability is the sexual reproduction, which allows individuals to better respond to changing environments (Li et al. 2002). Plants often show a diversity of mating systems ranging from obligatory autogamy associated with self-compatibility, to obligatory xenogamy associated to self-incompatibility, thus allowing variations in the transition between autogamy and allogamy (Iuchi \& Lopes 1997). Decades ago, Passiflora species were primarily considered xenogamous, conditioned by self-incompatibility (Semir \& Brown 1975).

Nowadays, there are reports of self-compatibility in wild and cultivated species, as $P$. edulis Sims (Menzel \& Simpson 1988, Souza et al. 2010). Americans and Europeans have cultivated ornamental passion flowers for years, and hybrids that show exotic beauty due to new combinations of colors have been used to decorate glasshouses and gardens (Abreu et al. 2009). Hybridization is a very important technique for plant breeding since it enables the recombination of alleles, thus allowing the production of new genetically superior materials (Bruckner 1997). The interspecific hybridization in passion flowers in Brazil has been primarily directed to the transfer of favorable characters of other species to $P$. edulis, especially resistance genes (Viana et al. 2003). Few studies have used this technique to develop ornamental hybrids (Abreu et al. 2009).

Sexual hybridization in passion flowers can be successfully carried out both among plants of the same species and among related species due to weak incompatibility barriers (Meletti et al. 2005). However, some crosses become unviable, a condition that can be solved by using biotechnological techniques, such as protoplast fusion, among others (Bruckner \& Otoni 1999, Marcelino et al. 2007).

Passiflora hybrids usually show exuberant flowers that are different in colours and size, and favorable for indoor decoration, whilst the genitors are small or do not have colored flowers (Ulmer \& MacDougal 2004). Passiflora capsularis L. and P. rubra L. are wild species found in Brazil, which can be used in breeding programs aiming to produce ornamental hybrids since they have small and abundant flowers, and foliage and fruits in colors and shapes favorable to ornamentation. These two species are closely related, and morphologically similar. The leaves of $P$. capsularis and P. rubra are similar so that, in the absence of flowers or fruits, it is difficult to distinguish them. The main differences between the two species remain in the ovary and the fruit. The ovary of $P$. rubra is densely covered with long trichomes that may be white or, more rarely, brown, which usually persist in the fruit. The ovary in $P$. capsularis is merely puberulent and its short hairs often disappear in the ripe fruit. Passiflora capsularis fruits are green and always more stretched, while in $P$. rubra fruits are crimson red and show greater variation in length and width, thus being more obovate (Sousa \& Meletti 1997).

This study aimed to estimate the outcrossing level in P. rubra and $P$. capsularis species, which shows a tight association with the breeding system and may support crossings involving these species in the production of ornamental plants.

\section{Material and methods}

Genotypes - Plant material was composed of four accessions of $P$. capsularis and four accessions of $P$. rubra. The accessions of $P$. capsularis were collected in the Atlantic forest of Southern Bahia state, at Morro da Viúva, PRNP Serra Bonita, Camacan, BA, Brazil, 144ㄱ' S, 3902' W, 789 m asl (accession BGP296), and also seeds from Empresa Brasileira de Pesquisa Agropecuária - Embrapa Cerrados, Planaltina, D.F. (accession BGP295), Universidade Estadual do Norte Fluminense Darcy Ribeiro - UENF, Campos dos Goytacazes, RJ (accession BGP260) and Instituto Agronômico - IAC, Campinas, SP (accession BGP297). The accessions of $P$. rubra were also collected at RPPN Serra Bonita (accession BGP265), at the same locality of $P$. capsularis, and also seed from Universidade Estadual Paulista - UNESP, campus de Jaboticabal, SP (accession BGP292), UENF (accession BGP293) and IAC (accession BGP294).

Cultivation conditions - Seeds were germinated in trays of 128 polystyrene cells. When the first true leaves were developed, the seedlings were transplanted to polyethylene bags with a volume of $1 \mathrm{~L}$, containing clay (argile) soil. After reaching $4.0 \mathrm{~cm}$ height, plants were transplanted into black pots of $43 \mathrm{~L}$, containing clay soil and substrate in a 3:1 ratio. Plants were grown in greenhouse at the Active Germplasm Bank of Passiflora, located at coordinates $14^{\circ} 39^{\prime} \mathrm{S}, 39^{\circ} 10^{\prime} \mathrm{W}$; $78 \mathrm{~m}$ asl. Pruning was carried out monthly, and fertilization with NPK (4-14-8) was performed every 60 days. Irrigation was accomplished through an automatic drip system. Pest control was conducted with chemical pesticides Decis ${ }^{\circledR}$ and Vertimec ${ }^{\circledR}$. Fungi were controlled by spraying products containing copper. Pests and diseases were controlled with 
simple preventive measures, not affecting the reproductive cycle of plants.

In vivo pollination - Flowers were tagged and bagged one day before opening. Although the beginning of flowers anthesis on P. capsularis was between 5:00 and 6:00 a.m. and in P. rubra it occurred between 5:30 and 7:30 a.m., all pollinations were performed at the same period, between 8:00 and 9:00 a.m.: a) Self-pollination - four flowers from each accession (16 flowers) were pollinated using anthers and stigmas of the same flower; b) intraspecific cross-pollination - four flowers from each accession were emasculated in the beginning of anthesis and the stigmas (without pollen grains) were pollinated with pollen from the other accessions; c) interspecific crosspollination - four flowers of each accession (per species) were emasculated before anthesis; anthers were mixed to form a bulk of the four accessions, which was used to pollinate all the flowers, hence making reciprocal crosses (P. capsularis vs. P. rubra; P. rubra vs. P. capsularis). Pollinations were performed with the help of tweezers as to carefully lean the anthers to the stigmas; the flowers were protected with paper bags for 24 hours after pollination. Five days after pollination, the fertilization index was verified, considering the fertilized flower that had initiated fruit development. After that, fruits were covered with a nylon mesh to protect against fall during ripening (Bruckner \& Otoni 1999).

In vitro pollen germination - Pollen germination test was performed as described for P. edulis Sims (Bruckner et al. 2000): $0.10 \mathrm{~g} \mathrm{~L}^{-1}$ boric acid $\left(\mathrm{H}_{3} \mathrm{BO}_{4}\right), 50 \mathrm{~g} \mathrm{~L}^{-1}$ sucrose, $0.3 \mathrm{~g} \mathrm{~L}^{-1}$ calcium nitrate tetrahydrate $\left(\mathrm{Ca}\left(\mathrm{NO}_{3}\right)_{2} \cdot 4 \mathrm{H}_{2} \mathrm{O}\right)$; $0.2 \mathrm{~g} \mathrm{~L}^{-1}$ magnesium sulfate heptahydrate $\left(\mathrm{MgSO}_{4} \cdot 7 \mathrm{H}_{2} \mathrm{O}\right)$ and $0.1 \mathrm{~g} \mathrm{~L}^{-1}$ potassium nitrate $\left(\mathrm{KNO}_{3}\right)$. One anther per flower was collected between 8:00 and 9:00 a.m., being the anther slightly hit on the slide to release pollen grains (PG) on a drop of germination medium previously autoclaved at $121^{\circ} \mathrm{C}$ for 15 minutes and mounted under a glass cover. The material was incubated in oven at $28 \pm 1{ }^{\circ} \mathrm{C}$ for 24 hours. We considered a PG germinated if it presented a pollen tube at least two times larger than its diameter.
Pollen-Ovule Ratio (P:O) - The P:O ratio was used as an indicator of the preferred mode of reproduction of the plant (Dafni 1992). The ovules and pollen grains were stained and counted according to Dafni (1992). The estimate of the reproduction mode for each species was carried out according to the classification of Cruden (1977): Cleistogamy $(<5.4)$; obligatory autogamy (5.5 to 39.0 ); facultative autogamy (39.1 to 396.9); facultative allogamy (397.0 to 2588.0) and obligatory allogamy (> 2588.0).

Statistical analysis - The experimental design used was totally randomized, consisting of four plants (treatment) maintained in protected cultivation. Replications were four for in vivo pollination and five for in vitro germination and $\mathrm{P}: \mathrm{O}$ ratio, represented by each flower, totalizing 16 flowers per type of in vivo pollination and species, and 20 flowers per species for in vitro germination and $\mathrm{P}: \mathrm{O}$ ratio. Data were subjected to a descriptive analysis and variance analysis using the software GENES (Cruz 2006).

\section{Results}

In vivo pollination - P. rubra and P. capsularis presented fruit set in over $60 \%$ of flowers self- and cross-pollinated and lower average values for interspecific pollination, in which the fruit set was above $46 \%$ for both species (table 1). The intra- and interspecific crosses showed no significant difference $(P<0.05)$ between species as for different treatments of pollination.

In vitro pollen germination - The results indicated significant differences $(P<0.05)$ among genotypes for the $P$. capsularis and also between the two species for the PG germination rate (tables 2 and 3).

Pollen-Ovule Ratio (P:O) - According to the mean values observed for the $\mathrm{P}: \mathrm{O}$ ratio, $P$. capsularis and $P$. rubra were classified as obligatory autogamous. There

Table 1. Mean percentage values of fertilization index for self-pollinations (Self-), intra-specific (Intra) and interspecific (Inter) cross-pollinations in Passiflora capsularis and P. rubra, considering four replications (plants) $(q=$ female genitor; $\mathrm{POL}=$ pollination; $\mathrm{sd}=$ standard deviation; $\mathrm{AC}=$ accession $)$.

\begin{tabular}{|c|c|c|c|c|c|c|}
\hline \multirow{2}{*}{ Species } & \multirow{2}{*}{ POL } & \multicolumn{5}{|c|}{$\%$ Mean* $( \pm$ sd) of accessions } \\
\hline & & AC 260 & AC 295 & AC 296 & AC 297 & Mean \\
\hline \multirow[t]{4}{*}{ P. capsularis } & Self- & $56.2 \pm 0,95$ & $68.7 \pm 0,95$ & $75.0 \pm 0,81$ & $50.0 \pm 1,41$ & 62.5 \\
\hline & Intra & $68.7 \pm 1,50$ & $62.5 \pm 1,00$ & $68.7 \pm 0,50$ & $75.0 \pm 0,81$ & 68.7 \\
\hline & Inter $q$ & $56.2 \pm 0,50$ & $37.5 \pm 0,57$ & $50.0 \pm 1,15$ & $50.0 \pm 0,81$ & 48.4 \\
\hline & & AC 265 & AC 292 & AC 293 & AC 294 & \\
\hline \multirow[t]{3}{*}{ P. rubra } & Self- & $68.7 \pm 0,50$ & $56.2 \pm 1,25$ & $62.5 \pm 1,29$ & $81.2 \pm 0,95$ & 67.2 \\
\hline & Intra & $81.2 \pm 0,50$ & $43.7 \pm 0,95$ & $62.5 \pm 1,00$ & $62.5 \pm 1,29$ & 62.5 \\
\hline & Inter $q$ & $56.2 \pm 0,50$ & $50.0 \pm 0,81$ & $43.7 \pm 0,50$ & $37.5 \pm 1,00$ & 46.9 \\
\hline
\end{tabular}

* Results are means of four repetitions (flowers) per plant. 
Table 2. Mean values for number of in vitro pollen grain (PG) germination in Passiflora capsularis and P. rubra, considering four replications (plants) $(\mathrm{sd}=$ standard deviation; $\mathrm{AC}=$ accession; $\mathrm{Germ}=$ germinated; $\mathrm{M}=$ mean).

\begin{tabular}{lcccc}
\hline \multirow{3}{*}{ Species } & \multicolumn{4}{c}{ Mean* $( \pm$ sd) of accessions } \\
\cline { 2 - 4 } & AC & $\begin{array}{c}\text { No PG } \\
\text { Germ }\end{array}$ & $\begin{array}{c}\text { \% PG } \\
\text { Germ }\end{array}$ & $\begin{array}{c}\text { PG } \\
\text { Total }\end{array}$ \\
\hline P. capsularis & 260 & $1939.0 \pm 110.3$ & 51.4 & 3775.7 \\
& 295 & $1929.5 \pm 64.8$ & 52.8 & 3651.7 \\
& 296 & $1997.2 \pm 74.4$ & 51.3 & 3895.0 \\
& 297 & $1762.7 \pm 166.9$ & 53.4 & 3300.0 \\
\hline \multirow{4}{*}{ P. rubra } & $\mathrm{M}$ & 1907.1 & 52.2 & 3655.6 \\
& 265 & $1703.5 \pm 141.8$ & 69.6 & 2448.0 \\
& 292 & $1538.5 \pm 139.2$ & 66.9 & 2300.7 \\
& 293 & $1671.5 \pm 149.8$ & 63.9 & 2615.7 \\
& 294 & $1454.5 \pm 118.5$ & 57.1 & 2549.5 \\
\hline
\end{tabular}

* Results are means of four repetitions (flowers) per plant.

Table 3. ANOVA summary for in vitro germination in Passiflora capsularis and P. rubra.

\begin{tabular}{lcc}
\hline Source of variation & DF & Mean squares \\
\hline P. capsularis & 3 & $40644.41^{*}$ \\
Error & 12 & 12444.54 \\
CV $(\%)$ & & 5.84 \\
P. rubra & 3 & $54765.33^{\mathrm{NS}}$ \\
Error & 12 & 18999.33 \\
CV $(\%)$ & & 8.66 \\
Between species & 1 & $796953.12^{*}$ \\
Error & 30 & 2118.52 \\
CV $(\%)$ & & 8.50 \\
\hline
\end{tabular}

$\mathrm{DF}=$ degrees of freedom $\mathrm{CV}=$ coefficient of variation. $*=$ Significance at the $5 \%(P<0.05)$ probability level by $\mathrm{F}$ test. ${ }^{\mathrm{NS}}=$ not significant. was no significant difference $(P<0.05)$ between species for the number of ovules and $P G$ number, while there was a significant difference $(P<0.05)$ between species for $P G$ number. The variation in the number of PG observed among species resulted in a significant difference by $\mathrm{F}$ test $(P<0.05)$ for the values of pollen-ovule ratio that was observed within and between species (tables 4 and 5).

\section{Discussion}

P. capsularis and $P$. rubra can reproduce both by self-pollination and cross-pollination and that crossing between the two species were well succeeded even

Table 4. Mean values for the number of pollen grains (PG), number of ovules and pollen-ovule ratio (P:O) in Passiflora capsularis and $P$. rubra, considering four replications (plants) $(\mathrm{sd}=$ standard deviation; $\mathrm{PL}=$ plants; $\mathrm{M}=$ mean).

\begin{tabular}{lcccc}
\hline \multirow{2}{*}{ Species } & \multirow{2}{*}{ AC } & \multicolumn{3}{c}{ Mean* $( \pm \mathrm{sd})$ of accessions } \\
\cline { 3 - 5 } & & PG & Ovules & P:O \\
\hline P. capsularis & 260 & $3031.4 \pm 698.5$ & $126.2 \pm 23.6$ & 24.0 \\
& 295 & $2342.8 \pm 235.9$ & $116.4 \pm 19.7$ & 20.1 \\
& 296 & $2949.6 \pm 590.3$ & $127.2 \pm 11.9$ & 23.2 \\
& 297 & $3207.4 \pm 272.9$ & $141.0 \pm 15.2$ & 22.4 \\
\cline { 2 - 4 } P. rubra & $\mathrm{M}$ & 2882.8 & 127.7 & 22.4 \\
& 265 & $3703.8 \pm 428.4$ & $145.8 \pm 17.6$ & 25.4 \\
& 292 & $4338.0 \pm 504.0$ & $145.6 \pm 20.9$ & 29.8 \\
& 293 & $3638.6 \pm 317.7$ & $132.8 \pm 18.5$ & 27.4 \\
& 294 & $3552.6 \pm 685.7$ & $131.2 \pm 28.9$ & 27.1 \\
\hline
\end{tabular}

\footnotetext{
* Results are means of four repetitions (flowers) per plant.
} 
Table 5. ANOVA summary for the variables number of pollen grains (PG), number of ovules, and pollen-ovule ratio (P:O) in Passiflora capsularis and P. rubra.

\begin{tabular}{lcccc}
\hline \multirow{2}{*}{ Source of variation } & DF & \multicolumn{3}{c}{ Mean squares } \\
\cline { 3 - 4 } & & PG & Ovules & P:O \\
\hline P. capsularis & 3 & $7050848.9^{\mathrm{NS}}$ & $511.8^{\mathrm{NS}}$ & $5.6180^{*}$ \\
Error & 16 & 241659.9 & 330.5 & 0.00002 \\
CV $(\%)$ & & 17.05 & 14.23 & 2.22 \\
P. rubra & 3 & $642804.8^{\mathrm{NS}}$ & $314.9^{\mathrm{NS}}$ & $6.5202^{*}$ \\
Error & 16 & 252195.8 & 482.3 & 0.00005 \\
CV $(\%)$ & & 13.18 & 15.81 & 2.57 \\
Between species & 1 & $3564577.0^{*}$ & $1243.2^{\mathrm{NS}}$ & $49.6506^{*}$ \\
Error & 38 & 314411.9 & 407.5 & 3.0413 \\
CV $(\%)$ & & 16.76 & 15.14 & 6.99 \\
\hline
\end{tabular}

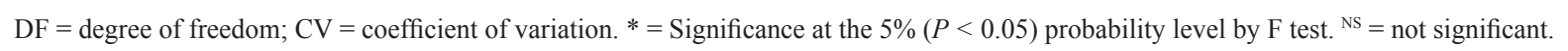

with a lower fertilization rate. Reproduction in most passion flowers occurs through cross-pollination due to the flower morphology, the anthers being located below the stigma; types of PG that are usually heavy and sticky; and, mainly, due to self-incompatibility in which pollen is unable to fertilize the ovules of the same plant, hence assuming that different plants may or not be compatible with each other (Bruckner et al. 2002, Souza et al. 2004).

Crossability tests on $P$. capsularis populations from Catas Altas, MG, Brazil, showed this species as selfcompatible (Faria \& Stehmann 2010). Reproduction in Passifloraceae may involve both self-compatible and self-incompatible systems. Self-incompatibility is understood as a mechanism that provokes allogamy and increases genetic variability (Varassin \& Silva 1999). Other species such as Byrsonima coccolobifolia Kunth (Malpighiaceae) have mixed reproductive system with high allogamy and autogamy levels. This system combines the advantages of self-pollination and cross-pollination, ensuring a high level of adaptability of population to the present environmental conditions associated with the maintenance of high evolutionary potential through recombination, which enables the species to colonize new and extensive areas (Scariot et al. 1991).

Variation in breeding systems is observed among Passiflora species and other genus of Passifloraceae: Mitostemma glaziovii Mast. can reproduce by xenogamy (95\% of the tested flowers) but it may also occur self-pollination and geitonogamy in a lower percentage (Benevides 2006); Passiflora alata is a species exclusively xenogamous, thus requiring cross-pollination for fruit set; on the other hand, P. suberosa L. is self-compatible with around $50 \%$ of fruit set when self-pollinated (Benevides 2006).

Some self-compatible species have a back up in case cross-pollination fails, i.e., if no pollen from a distinct individual reaches the stigma, the flower may be able to self-fertilize, hence ensuring seed production (Hmeljevski et al. 2007). The possibility of autogamy occurrence in the species studied would cause a reduction in the frequency of heterozygous forms and consequently increase the proportion of homozygous types. This occurrence should favor the generation of lineages for the production of hybrids (Allard 1999), besides the formation of seeds without the need for pollinators (Cardoso 2007).

In vitro germination of $\mathrm{PG}$ in $P$. capsularis and $P$. rubra was below $65 \%$. This is one of the methods for verifying the ability that $\mathrm{PG}$ have to emit pollen tubes and for fertilization. However, this method is influenced by different factors. There are species differences regarding the conditions required for pollen germination, mainly involving the constituents of the culture medium, temperature, and incubation time. Moreover, pollen viability is also influenced by development stage of the flower as for the collection of pollen and the storage conditions (Franzon et al. 2005).

Very low indexes of in vitro germination were obtained in P. suberosa, whereas for P. edulis f. flavicarpa, used as a control, the result was nearly $100 \%$ germination (Cruz et al. 2008). The average percentage of $P$. suberosa germination was negatively influenced by number of hours after anthesis, with a trend for percentage decrease during the period of flower opening (Cruz et al. 2008). Within just two hours after opening, the germination of pollen decreased $64 \%$, with the highest average 
germination obtained at 7:00 am., and the lowest at 05:00 p.m.. The same was observed by Souza et al. (2002) in P. edulis f. flavicarpa using chemical tests to assess pollen viability.

In $P$. capsularis and P. rubra, the values obtained were close to those observed for the control on $P$. edulis f. flavicarpa, which was only $76.9 \%$ of in vitro germination. This value differs from those found for the cultivated species by Bruckner et al. (2000) and Cruz et al. (2008). Such fact can be attributed to changes in the conditions of culture medium or procedure of in vitro cultivation, or even the manipulation of pollen during the experiment (Silva et al. 1999, Buckner et al. 2000). Results obtained in P. capsularis and P. rubra corroborate with the previous studies, since the low in vitro germination index obtained in this study may be related to the specific culture medium (Bruckner et al. 2000).

No viability or artificial in vitro germination test is quite satisfactory, especially after pollen has been stored, for the following reasons: the chemical tests employ dyes that react with chemical constituents or structures whose presence may not reflect the ability of the pollen to germinate; samples of PG that germinate in vitro may not produce sufficient elongation of the pollen tube as to affect fertility (Franzon \& Raseira 2006). On the other hand, for some species pollen samples that appear to be non-viable when tested in vitro can produce large percentage of seeds, and the pollen stored can differently germinate in repeated samples or in different culture media (Miranda \& Clement 1990). Maintaining the germination ability of pollen depends not merely on the inherent characteristics of the species, but also on storage conditions (Miranda \& Clement 1990, Frazon \& Raseira 2006).

In some cases, when spontaneous pollination occurs, autogamy allows the formation of seeds without the need for pollinators. This form of reproduction is used in breeding programs aiming to obtain homozygous lineages to produce hybrids from their crossings (Iuchi 1994). Allogamy may allow maintaining or increasing the hybrid vigor of the species by the occurrence of new combinations of genes that determine the traits of agronomic interest, as noted in Ocimum canum Sims (Lamiaceae), once allogamy has allowed greater production of essential oils that are widely used by pharmaceutical companies (Amaral et al. 2007).

The pollen-ovule ratio for brevistylus and longistylus flowers of Psychotria barbiflora DC (Rubiaceae) corresponded to the type of reproductive system involving the facultative xenogamy (Teixeira
\& Machado 2004). However, other methods such as the controlled pollinations and the analysis of pollen tube growth used to evaluate the reproductive system in Psychotria barbiflora confirmed that the species showed obligatory xenogamy, thus depending on the efficiency of pollinators for their maintenance (Teixeira $\&$ Machado 2004). These results were similar to those obtained in our studies for $P$. capsularis and $P$. rubra that were categorized as obligatory, according to values obtained by the P:O ratio (Cruden 1977). But, when comparing these results to those of controlled pollination, it was observed that both species can reproduce either by selfpollination or by intraspecific pollination.

Although the $\mathrm{P}: \mathrm{O}$ ratio has been widely used to characterize the breeding system of many species, the factors that determinate the $\mathrm{P}: \mathrm{O}$ ratio are not clear (Wyatt 1984). Vasek \& Weng (1988) suggested that the interpretation of $\mathrm{P}: \mathrm{O}$ ratio is not the only way to characterize the reproductive system of a species and that methods of evaluating the $\mathrm{P}: \mathrm{O}$ ratio must be standardized at family level. Characterization of the reproductive system in $P$. capsularis and P. rubra could be used for establishing genetic breeding strategies aiming to produce inter-specific hybrids.

In conclusion, the use of in vitro germination for tests on pollen of $P$. capsularis and P. rubra using medium and conditions described in the methodology provides satisfactory results when compared to in vivo germination. Analysis on the P:O ratio proved to be inefficient in determining the reproductive system in the two passion flower species studied since they were classified as obligatory autogamous.

Acknowledgements - The authors thank to Conselho Nacional de Desenvolvimento Científico e Tecnológico $(\mathrm{CNPq})$ for the scholarship to the first author; the Fundação de Amparo à Pesquisa do Estado da Bahia (FAPESB) and Universidade Estadual de Santa Cruz (UESC) by the financial support to this investigation, and Dr. Vitor O. Becker by the permission of collecting the passion fruits in the Reserva Particular do Patrimômio Natural (RPPN) of Serra Bonita BA, Brazil.

\section{References}

ABREU, P.P., SOUZA, M.M., SANTOS, E.A., PIRES, M.V., PIRES, M.M. \& ALMEIDA, A.A.F. 2009. Passion flower hybrids and their use in the ornamental plant market: perspectives for sustainable development with emphasis on Brazil. Euphytica 166:307-315.

ALLARD, R.W. 1999. Principles of plant breeding. John Wiley \& Sons, New York. 
AMARAL, C.L.F., ALMEIDA, O.S., SILVA, A.B. \& BRITO, A.C. 2007. Tendências reprodutivas de Ocimum canum Sims. (Lamiaceae) subsidiando programas de melhoramento genético. Diálogos \& Ciência 12:1-11.

BENEVIDES, C.R. 2006. Biologia floral e polinização de Passifloraceae nativas e cultivadas na região Norte Fluminense-RJ. Dissertação de Mestrado, Universidade Estadual do Norte Fluminense Darcy Ribeiro, Campos dos Goytacazes.

BERNACCI, L.C., VITTA, F.A. \& BAKKER, Y.V. 2003. Passifloraceae. In Flora Fanerogâmica do Estado de São Paulo (M.G.L. Wanderley, G.J. Shepperd, T.S. Melhem, A.M. Giulietti \& M. Kirizawa, eds.). RiMa/FAPESP, São Paulo, v.3, p.247-274.

BORÉM, A. 1999. Hibridação artificial de plantas. Editora UFV, Viçosa.

BRUCKNER, C.H. 1997. Perspectivas do melhoramento genético do maracujazeiro. In Maracujá: temas selecionados (I. Manica, C.H. Bruckner \& M. Hoffmann, eds.). Cinco Continentes Editora, Porto Alegre, p. 25-46.

BRUCKNER, C.H., CASALI, V.W.D., MORAES, C.F., REAZZI, A.J. \& SILVA, E.A.M. 1995. Selfincompatibility in passion fruit (Passiflora edulis Sims). Acta Horticulturae 370:45-57.

BRUCKNER, C.H., MELLETI, L.M.M., OTONI, W.C. \& ZERBINI JR., F.M. 2002. Maracujazeiro. In Melhoramento de fruteiras tropicais (C.H. Bruckner, ed.). Editora UFV, Viçosa, p.373-409.

BRUCKNER, C.H. \& OTONI, W.C. 1999. Hibridação em maracujá. In Hibridação artificial de plantas (A. Borém, ed.). Editora UFV, Viçosa, p.379-399.

BRUCKNER, C.H., SILVA, M.M., FALLEIRO, T.M., ANDRADE, B.B. \& MOREIRA, A.E. 2000. Viabilidade do pólen de maracujazeiro sob diferentes condições de armazenamento. Revista Ceres 47:523-531.

CARDOSO, A.I.I. 2007. Produção de pimentão com vibração das plantas. Ciência e Agrotecnologia 31: 1061-1066.

CERVI, A.C. 2005. Espécies de Passiflora L. (Passifloraceae) publicadas e descritas nos últimos 55 anos (1950-2005) na América do Sul e principais publicações brasileiras. Estudos de Biologia 27:19-24.

CERVI, A.C. 2006. O gênero Passiflora L. (Passifloraceae) no Brasil, espécies descritas após o ano de 1950. Adumbrationes ad Summae Editionem 16:1-5.

CRONQUIST, A. 1981. An integrated system of classification of flowering plants. Columbia University Press, New York.

CRUDEN, R.W. 1977. Pollen-ovule ratios: a conservative indicator of breeding systems in flowering plants. Evolution 31:32-46.

CRUZ, C.D. 2006. Programa Genes - Estatística experimental e matrizes. Editora Universidade Federal de Viçosa Viçosa.
CRUZ, T.V., SOUZA, M.M., ROZA, F.A., VIANA, A.J.C., BELO, G.O. \& FONSECA, J.W.S. 2008. Germinação in vitro de grãos de pólen em Passiflora suberosa L. para sua utilização em hibridação interespecífica. Revista Brasileira de Fruticultura 30:875-879.

DAFNI, A. 1992. Pollination ecology: a practical aproach. IRL, Oxford.

FARIA, F.S. \& STEHMANN, J.R. 2010. Biologia reprodutiva de Passiflora capsularis L. e P. pohlii Mast. (Decaloba, Passifloraceae). Acta Botanica Brasilica 24:262-269.

FEUILLET, C. 2004. Passifloraceae (passion flower family). In Flowering plants of the Neotropics (N. Smith, S.A. Mori, A. Henderson, D.W. Stevenson \& S.V. Heald, eds.). Princeton University Press \& New York Botanical Garden, Oxford, p.286-287.

FRANZON, R.C. \& RASEIRA, M.C.B. 2006. Germinação in vitro e armazenamento do pólen de eugenia involucrata DC. (Myrtaceae). Revista Brasileira Fruticultura 28:18-20.

FRAZON, R.C., CORRÊA, E.R. \& RASEIRA, M.C.B. 2005. In vitro pollen germination of feijoa (Acca sellowiana (Berg) Burret). Crop Breeding and Applied Biotechnology 5:229-233.

HMELJEVSKI, K.V., REIS, A., REIS, M.S., ROGASLSKI, J.M., NETO, C.D. \& LENZI, M. 2007. Resultados preliminares da biologia reprodutiva de Dyckia ibiramensis Reitz (Bromeliaceae): uma espécie rara e endêmica de Santa Catarina. Revista Brasileira de Biociências 5:267-269.

IUCHI, V.L. 1994. Morfologia, biologia floral, propagação e crescimento de "rainha do abismo" (Sinningia leucotrichia Hoene). Tese de Doutorado, Universidade Federal de Viçosa, Viçosa.

IUCHI, V.L. \& LOPES, L.C. 1997. Desenvolvimento floral de Sinningia leucotricha (Hoehne) Moore - Gesneriaceae (rainha-do-abismo). Revista Brasileira de Horticultura Ornamental 3:58-63.

JUDD, W.S., CAMPBELL, C.S., KELLOGG, E.A. \& STEVENS, P.F. 1999. Plant systematics: a phylogenetic approach. Sinauer Associates Inc., Sunderland.

KOSCHNITZKE, C. \& SAZIMA, M. 1997. Biologia Floral de cinco espécies de Passiflora L. (Passifloraceae) em mata semidecídua. Revista Brasileira de Botânica 20:19-126.

LI, Q.J., KRESS, W.J., XU, Z.F., XIA, Y.M., ZHANG, L., DENG, X.B. \& GAO, J.Y. 2002. Mating system and stigmatic behavior during flowering of Alpinia $k$ wangsiensis (Zingiberaceae). Plant Systematics and Evolution 232:123-32.

MARCELINO, F.C., BINNECK, E., ABDELNOOR, R.V. \& NEPOMUCENO, A.L. 2007. Ferramentas biotecnológicas aplicadas à cultura da soja. Circular Técnica 47. Embrapa Soja, Londrina.

MELETTI, L.M.M., SANTOS, R.R. \& MINAMI, K. 2000. Breeding of yellow passion-fruit: development of the cultivar Composto IAC-27. Scientia Agricola 57:491-498. 
MELETTI, L.M.M., SOARES-SCOT, M.D., BERNACCI, L.C. \& PASSOS, I.R.S. 2005. Melhoramento genético do maracujá: passado e futuro. In Maracujá: germoplasma e melhoramento genético (F.G. Faleiro, N.T.V. Junqueira \& M.F. Braga, eds.). Embrapa Cerrados, Planaltina, p.55-78.

MENZEL, C.M. \& SIMPSON, D.R. 1988. Effect of continous shading on growth, flowering and nutrient uptake of passion fruit. Scientia Horticulturae 35:77-88.

MIRANDA, P.A. \& CLEMENT, C.R. 1990. Germination and storange of pejibaye (Bactris gasipaes) palmae pollen. Revista de Biología Tropical 38:29-33.

NUNES, T.S.L. 2002. A família Passifloraceae no estado da Bahia, Brasil. Dissertação de mestrado, Universidade Estadual de Feira de Santana, Feira de Santana.

NUNES, T.S. \& QUEIROZ, L.P. 2007. Uma nova espécie de Passiflora L. (Passifloraceae) para o Brasil. Acta Botanica Brasilica 21:499-502.

PATERNIANI, M.E.A.G.Z. 2001. Use of heterosis in maize breeding: history, methods and perspectives - a review. Crop Breeding of Applied Biotechnology 1:159-178.

REIS, A., ROGALSKI, J.M., VIEIRA, N.K., BERKENBROCK, I.S. \& PUCHALSKI, A. 2005. Conservação de espécies reófitas de Dyckia no Sul do Brasil: Dyckia disachya. Relatório Técnico para Fundação Biodiversitas (Programa de Espécies Ameaçadas). Universidade Federal de Santa Catarina, Florianópolis.

RICHARDS, A.J. 1986. Plant breeding systems. George Allen \& Unwin, London.

SCARIOT, A.O., LLERAS, E. \& HAY, J.D. 1991. Reproductive biology of the Palm Acrocomia aculeata in Central Brazil. Biotropica 23:12-22.

SEMIR, J.K.S. \& BROWN, J.R. 1975. Maracujá: a flor da paixão. Revista Geográfica Universal 5:40-47.

SILVA, M.M., BRUCKNER, C.H., PICANÇO, M. \& CRUZ, C.D. 1999. Fatores que afetam a germinação do grão de pólen do maracujá: meios de cultura e tipos de agrotóxicos. Pesquisa Agropecuária Brasileira 34: 347-352.

SOUSA, J.S.I. \& MELETTI, L.M.M. 1997. Maracujá: espécies, variedades, cultivo. Fundação de Estudos Agrários Luiz de Queiroz - FEALQ, Piracicaba.
SOUZA, M.M., PEREIRA, T.N.S., VIANA, A.P., PEREIRA, M.G., AMARAL JR., A.T. \& MADUREIRA, H.C. 2004. Flower receptivity and fruit characteristics associated to time of pollination in the yellow passion fruit Passiflora edulis Sims f. Alavicarpa Degener (Passifloraceae). Scientia Horticulturae 101:373-385.

SOUZA, M.M., PEREIRA, T.N.S. \& MARTINS, E.R. 2002. Microsporogênese e microgametogênese associadas ao tamanho do botão floral e da antera e viabilidade polínica em maracujazeiro-amarelo (Passiflora edulis Sims f. flavicarpa Degener). Ciência e Agrotecnologia 26:1209-1217.

SOUZA, M.M., VIANA, A.P. \& PEREIRA, T.N.S. 2010. A putative mutant of a self-compatible yellow passion fruit with the corona color as a phenotypic marker. Bragantia 69:9-16.

TEIXEIRA, L.A.G. \& MACHADO, I.C. 2004. Biologia da polinização e sistema reprodutivo de Psychotria barbiflora DC. (Rubiaceae). Acta Botanica Brasilica 18:853-862.

ULMER, T. \& MACDOUGAL, J.M. 2004. Passiflora passionflowers of the World. Timber Press, Portland.

VARASSIN, I.G. \& SILVA, A.G. 1999. A melitofilia em Passiflora alata Dryander (Passifloraceae) em vegetação de restinga. Rodriguésia 50:5-17.

VASEK, F.C. \& WENG, V. 1988. Breeding systems of Clarkia section Phaeostoma (Onagraceae): I. Pollenovule ratios. Systematic Botany 13:336-350.

VIANA, A.P., PEREIRA, T.N.S., PEREIRA, M.G., SOUZA, M.M., MALDONADO, J.F.M. \& AMARAL JR., A.T. 2003. Genetic diversity among yellow passion fruit commercial genotypes and among Passiflora species using RAPD. Revista Brasileira de Fruticultura 25: 489-493.

VIANA, A.J. 2009. Delimitação entre as espécies Passiflora edulis Sims e Passiflora sp. nativa da Bahia com base em características citogenéticas, moleculares e morfológicas. Dissertação de Mestrado, Universidade Estadual de Santa Cruz, Ilhéus.

WYATT, R. 1984. Evolution of self-pollination in granite outcrop species of Arenaria (Caryophyllaceae). III. Reproductive effort and pollen-ovule ratios. Systematic Botany 9:432-40. 